\title{
The path from social origins to top jobs: social reproduction via education
}

\begin{abstract}
This paper provides a comprehensive account of the way in which cognitive and educational attainment mediate the link between social origins and elite social class destinations in mid-life. Using the 1970 British Cohort Study (BCS70), we assess the roles of a range of pathways through which educational advantage may lead to occupational attainment: cognitive development; private and selective secondary schools; school level qualifications; and higher education, including institution and field of study. Whereas past research has shown a residual direct effect of social origins on class destinations, we find that, once a sufficiently detailed picture of educational attainment is taken into account, education fully explains the link between social origins and top social class destinations. In contrast, the gap between men and women in achieving top social class positions is in no part accounted for by education.
\end{abstract}

Social reproduction is the obverse of social mobility, and refers to the way in which parents pass on their socio-economic advantages and disadvantages to their children. The role of the education system in this process is undeniably powerful (Bourdieu and Passeron [1977] 1990; Bowles and Gintis 1976; Jencks 1979). Yet past evidence has shown a persistent direct link between social origins and destinations which cannot be fully explained by educational attainment (Bernardi and Ballarino 2016; Breen and Goldthorpe 2001; Bukodi and Goldthorpe 2011; Devine and Li 2013; Gutierrez, Micklewright and Vignoles 2015). The view that the direct role of social origins is declining has been challenged by recent research (Bukodi et al. 2016 ), and there remains a consensus that the 'Origins-EducationDestinations' (OED) triangle retains a direct Origins-Destinations link (Breen 2004). A growing literature has explored the potential mechanisms underpinning this residual direct link, including the role of social networks (Gutierrez, Micklewright and Vignoles 2015) and so-called 'soft' or 'non-cognitive' skills (Blanden, Gregg and Macmillan 2007; Jackson 2007). This paper focusses on the path to positions at the top end of the social class distribution, and challenges the current consensus by showing that, for the generation born in 
1970 , the path from social origins to the top class occupations is fully accounted for by educational pathways. An important advantage of our study is that we are able to provide a uniquely refined account of educational attainment throughout the educational career. The residual direct effect of social origins on occupational outcomes has the status of a stylized fact within sociology, yet we argue that this finding is potentially an artefact of the failure to measure education adequately.

The growing gap between the richest and the rest (Piketty, Goldhammer and Ganser 2014), combined with declining rates of absolute upward social mobility (Bukodi et al. 2015), has led to renewed academic and policy attention to the question of access to elite occupations and incomes (Social Mobility and Child Poverty Commission 2015). Unpacking the link between childhood social origins and adult destinations (Halsey, Heath and Ridge 1980) remains a central concern for sociologists. But the processes of social reproduction and mobility at the top end of the social distribution may be distinctive, potentially with a smaller direct role for social origins (Torche 2011), and a greater reliance on educational distinctions which are not typically captured within standard approaches. What are the roles of selective and private schooling and elite universities in the social reproduction of the socio-economic elite? And is education sufficient to explain the link between social origins and elite socioeconomic destinations in England and Wales?

Social reproduction is shaped by gender as well as class, and women in mid-life and beyond continue to be lower paid than men at the same level of qualifications (Joshi, Makepeace and Dolton 2007) and are less likely to be employed at the top end of the socio-economic distribution, despite equal or higher educational attainments. We consider whether it is possible to account for the gender gap with a more refined treatment of educational attainment. 
Our paper advances on past work on the origins-education-destinations link in the way it accounts for a range of educational mechanisms via which families and individuals may increase their chances of enjoying an advantaged socio-economic position in adulthood. These mechanisms include: cognitive attainment and development during childhood; private and selective schooling; school examination performance; and finally, gaining a university degree, especially from an elite institution or in a prestigious field.

\section{Educational inequalities from early childhood to Higher Education} Socio-economic inequalities in educational attainment develop throughout the life course, and are apparent from early childhood onwards (Duncan and Magnuson 2011; Farkas and Beron 2004; Feinstein 2003; Sullivan, Ketende and Joshi 2013). Therefore, it is vital to take the role of early cognitive development into account in order to understand the development of inequalities in the life course, and avoid over-stating the role of subsequent selection into elite education. Some analysts treat cognitive scores as reflecting inherent intelligence or genetic endowment (Saunders 2010). In contrast, we see children's cognitive scores as also reflecting the outcome of learning processes at home, at school, and beyond. Cognitive scores are susceptible to development and change, but differ importantly from educational qualifications in that they are the products of 'low stakes' tests, and lack signalling value in the labour market. They are an important predictor of educational success (Marks 2013), but may also have a direct influence on occupational outcomes.

Another educational mechanism through which parents can seek to pass on their advantages is through private and selective schooling. In the UK context, the over-representation of the privately educated in top jobs continues (Macmillan, Tyler and Vignoles 2015). People who have attended private and grammar schools are advantaged in terms of school qualifications (Feinstein and Symons 1999; Sullivan and Heath 2003) and in terms of income and 
occupational attainment (Crawford and Vignoles 2014; Dearden, Ferri and Meghir 2002; Green et al. 2012; Green et al. In press; Iannelli 2013; McKnight 2015). Private school pupils also have a higher chance of gaining a degree from an elite university than state school pupils with the same school level qualifications (Sullivan et al. 2014). Advocates of selective schooling continue to claim that it represents a route to social mobility for working-class pupils, despite these pupils being less likely to attend grammar schools (Boliver and Swift 2011; Burgess, Dickson and Macmillan 2014).

The sociological theories of Maximally Maintained Inequality (MMI) (Raftery and Hout 1993), and Effectively Maintained Inequality (EMI) (Lucas 2001), state that, as education systems expand, and access to any given level of education becomes near-universal, inequalities will be maintained via access to the next level (MMI), or via status distinctions within a given level (EMI). So, for example, if inequalities in access to a university degree diminish, their role will be displaced by differentials in access to high status universities and courses. It is therefore vital to take account of such educational differentials in a refined way in order to capture the role of education in accounting for the link between origins and elite social class destinations. Young people from poorer backgrounds are less likely that those from better off families to go to university at all, and those who do go are less likely to attend high status institutions (Crawford et al. 2016). As well as status differentials between universities, there are also differences in status and wage returns between degrees in different subject areas (Croxford and Raffe 2015; Jackson et al. 2008; Kim, Tamborini and Sakamoto 2015; Ma and Savas 2014; O Leary and Sloane 2005; Patrignani and Conlon 2011; Walker and Zhu 2011; Walker and Zhu 2013). 


\section{Research questions}

This paper considers outcomes for the 1970 British Cohort Study (BCS70) at age 42. The link between social origins and destinations grows stronger during the occupational career (Bernardi and Ballarino 2016), so an assessment of this link in mid-life, when career trajectories are well-established, is ideal. Recent research has advanced our understanding of elite formation using rich cross-sectional data (Wakeling and Savage 2015a; Wakeling and Savage 2015b). The current study uniquely contributes to this literature from a life course perspective, examining the extent to which the origins-destinations link is accounted for by cognitive and educational attainment and by the type of educational institutions attended and level of qualifications gained throughout the educational career. While previous research on occupational attainment has examined aspects of cognition or qualifications, private schooling or higher education, to our knowledge, this is the first study to address all of these in conjunction.

1. Our over-arching research question is: to what extent can the link between origins and destinations be accounted for by a refined life-course account of cognitive and educational attainment? Is there a residual social origins effect which cannot be explained by education?

2. We also consider whether there is a decisive factor or stage in the educational trajectory which accounts for the origins-destinations link.

a. To what extent have inequalities already crystallised on entry to primary or secondary school, and to what extent do they emerge later in the educational career? 
b. To what extent do private and selective secondary schooling lead to elite social destinations in mid-life, and to what extent does the ability of advantaged parents to place their offspring in private and grammar schools account for their offspring's occupational success?

c. Does university level education, including institutional status and field of study, influence outcomes and further mediate the origins-destinations link?

\section{Data, variables and methods}

The 1970 British Cohort Study (BCS70) follows the lives of more than 17,000 people born in England, Scotland and Wales in a single week of 1970 (Chamberlain et al. 1975; Elliott and Shepherd 2006). An understanding of the educational progress of this cohort during their childhood is vital to understanding their later life course trajectories.

BCS70 is particularly rich in measures of cognition. We make use of the full set of cognitive tests at the ages of 5, 10 and 16. We use varimax Principal Components Analysis (PCA) to extract a single main component score for cognition using all available tests at each age. The resulting PCA score is standardised in our analyses. Full information on the BCS70 cognitive scores is provided by Parsons (2014).

Within the private sector, it is important to distinguish between elite 'public' schools and other private schools, as it is the 'public' schools that most strongly dominate the British ruling elite (Kirby 2016). We have used the 'Tatler', list of 'public' schools to identify the most prestigious establishments. We therefore distinguish between the following secondary 
school sectors: 'Tatler' (most prestigious private), private (other), grammar (state academically selective schools), secondary modern (state schools for those not selected for grammars) and comprehensive (all-ability state schools).

We also exploit fine-grained data on higher education collected at age 42. Our measure of an elite university is based on the Russell Group ${ }^{\mathrm{ii}}$ of universities, which promotes itself as representing the leading UK universities (Boliver 2013) ) $^{\mathrm{iii}}$. We acknowledge the element of arbitrariness in this measure, but substantial cultural as well as economic differences between Russell Group and other university graduates are apparent (Sullivan and Brown 2015). We include anyone gaining a degree awarded by a polytechnic within the non-elite degree category. Following Walker and Zhu (2011), we group degree subjects into: STEM (Science, Technology, Engineering and Mathematics), LEM (Law, Economics and Management) and OSSAH (other social sciences, arts and humanities, including languages - in what follows, we sometimes refer to this category as 'humanities').

We exploit data from all of the childhood waves of BCS70, and therefore the problem of missing data must be addressed (Mostafa and Wiggins 2015). As list-wise deletion/complete case analysis returns biased estimates, we use multiple imputation with chained equations (20 imputed datasets) to 'fill-in' values of any missing items in the variables selected for our analysis adopting Schafer's data augmentation approach (Schafer 1997) under the assumption of 'missing at random' (MAR). In order to maximise the plausibility of the MAR assumption we also included a set of auxiliary variables in our imputation model. In this instance MAR implies that that our estimates are valid if missingness is due to variables (auxiliary or substantive) that were included in our models (Little and Rubin 2002). 
Our analytical sample includes all cohort members resident in England and Wales in 1986 with a full set of birth characteristics, who participated in the age 42 survey and had information on school type and on our dependent variable. Cohort members resident in Scotland were excluded because Scotland's system of school qualifications differs from that in England and Wales. This leaves us with an analytical sample of 7102 cases, for which missing values are imputed. All reported analyses are averaged across 20 replicates based upon Rubin's Rule for the efficiency of estimation under a reported degree of missingness across the whole data of around 0.20 .

As we are interested in elite formation, we examine differences in access to the top of the social class spectrum. We identify the top social class group using the NS-SEC (Rose and O'Reilly 1998) occupational schema, which determines class position in terms of employment relations. It reflects not just income, but longer term economic security, stability and prospects, as reflected in a person's occupation and employment status. It also reflects power in terms of relationships of authority, control and autonomy within the workplace (Goldthorpe and McKnight 2006). We examine access to the top NS-SEC class (class 1, comprising 1.1 and 1.2). Class 1.1 consists of large employers and higher managerial and administrative occupations such as chief executives, production managers and senior police officers. Class 1.2 consists of higher professional occupations, such as lawyers and doctors. Some major graduate occupations are not included in class 1 , because they are subject to a relatively high degree of day-to-day managerial control. For example, school teachers, librarians and social workers are in class 2, 'lower managerial, administrative and professional occupations'. We use NS-SEC so that our findings can speak directly to the mainstream of sociological work in this field. It is likely that alternative measures of the top end of the socio-economic scale, such as those based on income (Laurison and Friedman 
2016), wealth (Blanden and Machin 2017), social status (Prandy 1990), or broader cultural measures (Savage et al. 2013) may yield different results, and an investigation of such differences could yield important additional insights into social reproduction and mobility processes.

\section{British schools and universities in historical context}

The majority (81\%) of the 1970 cohort attended comprehensive state secondary schools (for all abilities), with minorities attending selective state grammar schools (4\%) for those who passed the '11-plus' competitive entrance exam, secondary modern schools (9\%) for those who failed, and private schools (6\%). The 1970 cohort took public examinations at age $16,(\mathrm{O}$ levels (Ordinary Levels) for the more academic and CSEs (Certificate of Secondary Education) for the rest. A top grade CSE pass was deemed equivalent to an O level grade C. A minority of pupils stayed on at school from 16-18 to take A (Advanced) level courses, which were (and remain) the main academic university-track qualification.

Private schools in the 1980 s were in a position to take advantage of the decline of grammar schools, by providing an academically selective education for those able to pay, though they may also have lost some of their previous business in 11-plus failures from affluent families. Private schools responded to increasing reliance on academic qualifications in the labour market by increasing their focus on academic attainment (Green et al. 2012; Rae 1981). In contrast, state schools faced particular difficulties during the 1980 s due to education cuts under the Thatcher government (Gillard 2011).

British school leavers in the late 1980s still had access to means-tested maintenance grants, paid for by the state. All universities were public, and none charged tuition fees. University entrance requirements were largely based on the A level grades achieved by the applicant. 
Higher education institutions were divided into universities and polytechnics (the latter being lower in status). Despite the subsequent abolition of the university/polytechnic divide, status differentials between British universities have not diminished in importance.

\section{Analysis}

Our analysis proceeds in three sections. First, we present a descriptive analysis of the top social class in terms of our explanatory variables, and show a correlation matrix of key cognitive and educational measures used in the subsequent analysis. Second, we show a series of logistic regression models, using STATA. Third, we present a Structural Equation Model (SEM), using Mplus.

\section{Descriptive analysis}

Table 1 shows the frequencies for the independent variables, the proportions in each category in the top social class group, and the composition of the top class. Overall, class 1 represents 15 per cent of the sample. Men (19\%) are nearly twice as likely to be in class 1 as women (11\%). The top social class is composed of 64 per cent men and 36 per cent women.

\section{TABLE 1}

Clear differences in social class destinations according to social origins are apparent. Seventeen per cent of the sample had at least one parent with a university degree, whereas a third (33\%) had parents with no qualifications. Those with graduate parents had over three times the likelihood of reaching top social class positions compared to their peers whose parents had no qualifications (28\% compared with $9 \%$ ). This means that, while nearly a third of incumbents of social class 1 hail from graduate parents (32\%), a fifth (20\%) can be said to come from entirely uneducated social origins, as their parents had no qualifications. 
Occupational social class is measured at birth using the Registrar General's classification, as NS-SEC (Goldthorpe 1997) is not available for 1970. A quarter of the sample (25\%) were born into class I or II, and these individuals had a greater chance than their peers of being in class 1 in mid-life (23\% compared to $10 \%$ for those in the lowest category of class origins). Nevertheless, class 1 is not dominated by individuals from the highest social class origins, a majority of individuals in this class $(63 \%)$ originate from lower down the class scale. This highlights the point that absolute levels of social mobility are not as low as commentators have sometimes assumed (Payne 2017).

There is a strong, yet hardly decisive, gradient between cognitive scores in childhood and adult social class and earnings. For example, those in the top quartile of cognitive scores at age ten were relatively likely to achieve top social class positions (28\%) compared to those in the bottom quartile (5.3\%). However, this means that the majority $(51 \%)$ of those in the top social class at age 42 did not score in the top quartile of the cognitive distribution at age ten.

Turning to secondary school types, people who had been to secondary modern schools had the lowest chance of being in class $1(9 \%)$, followed by comprehensive pupils (14\%), grammar pupils (24\%), and non-Tatler private schools (35\%). Those who had been to top private schools were most likely to be in the top social class in mid-life (39\%). Nevertheless, $74 \%$ of those in class 1 had attended comprehensive schools.

Overall performance in public examinations at age 16 , as well as specific attainment in maths and English, was associated with a higher change of being in social class 1 . For example, $27 \%$ of those who achieved a good pass in mathematics at age 16 were in class 1 at age 42 , compared to $8.4 \%$ of their peers without this qualification. This means that a majority of 
those in social class $1(65 \%)$ had a good maths O level pass. Those who gained three or more good A level passes had a distinct advantage in achieving a top class occupation (44\% compared to $11 \%$ of those without A levels).

People without a university degree were much less likely to be in class $1(9 \%)$ than those who had gained degrees ( $35 \%$ on average). However, class 1 is by no means exclusively composed of university graduates - a bare majority (55\%) of this class have a degree. There were large differences according to institutional status and field of study. Among graduates, those with OSSAH degrees from non-elite institutions had the lowest likelihood (21\%) of being in the top social class, followed by OSSAH graduates from elite universities (30\%). Both STEM and LEM graduates from non-elite universities had a higher change of being in the top social class (41\%) than OSSAH graduates from elite universities. Those with elite degrees in STEM (57\%) and LEM (59\%) had the greatest chance of ending up in the top social class.

Overall, table 1 shows a clear pattern of advantage for those from relatively privileged social origins and for those with high levels of cognitive and educational attainment, but it also shows that these relationships are far from deterministic, and there is a good deal of mobility and variability in outcomes, which is incompatible with simplistic accounts of either social reproduction or meritocracy (Jencks 1972).

Table 2 shows a correlation matrix of the key cognitive and educational measures used in our models. Correlations range between 0.28 (for cognition at age 5 and A levels) and 0.68 (cognition at 10 and cognition at 16). The inter-correlation between the three cognitive scores is fairly strong (average $r=0.58$ ). In turn, the cognitive scores all correlate positively with 
public exam and degree achievements although the cognitive score at age ten is particularly informative.

\section{TABLE 2}

\section{Logistic regression analysis}

Our logistic regression analysis consists of six models, each of which adds successive blocks of variables to capture distinct stages of the educational life course. Our aim is to show the extent to which the influence of social origins upon the chances of being in the highest social class by the age of 42 is mediated by cognitive and educational attainment and by educational institutions at each stage.

Model 1 includes only gender and social origins, measured by parents' qualifications, income and social class. We retain these three separate measures, as they express different, though overlapping, sets of parental resources (Bukodi and Goldthorpe 2012), and we might expect the effect of parental education on the child's occupational outcomes to be fully mediated by the child's own educational attainment, while this may not be the case for parental income and occupational social class. We use the highest occupation based on either the mother or father's current or most recent job. Parents' highest qualification (in 1975) is coded as mother's or father's whichever is highest. Family income (in 1980) is coded on a seven point scale from $<£ 35$ to $>£ 250$ per week.

Model 2 includes cognition at age five, around the start of primary school. 
Combined cognitive scores at each age (five, ten and 16) are derived from the range of tests taken by the cohort members, and transformed into standardised scores (Parsons 2014).

Model 3 includes cognitive scores at age ten, towards the end of primary school.

Model 4 adds the type of secondary school attended (1986), comprehensive, grammar, secondary modern, or private. In the case of boys, we distinguish between the more exclusive 'public' schools from the Tatler list, and other private schools.

Model 5 includes qualifications and cognitive scores up to age 20 (typically taken at age 1618). Our measures of examination results at age 16 (1986) include a derived total point score from all O level and CSE examinations. We also include separate binary variables to indicate whether a cohort member had a maths or English O Level grade A-C or equivalent. A levels (typically taken at age 18) were (and remain) the university-track qualification in England and Wales.

Model 6 includes the type of university (Russell Group or not) and the subject discipline of the degree.

Logistic regression results Table 3 shows the results of our analysis of the chances of achieving NS-SEC class 1. Model 1 shows the association between social origins in terms of parental education, social class and income, and social class destinations at age 42. Social class of origin, parental educational qualifications and family income are all positive predictors of being in the top social class category in mid-life. The largest advantage is for those with a university graduate parent, this conferred 2.8 times the odds of getting into the top social class, compared to those whose parents had no qualifications. Women had roughly half the odds of achieving a top social 
class position, and this difference is stable across our models - i.e. it is not accounted for by any aspect of educational attainment. In supplementary analysis, we ran separate regressions for men and women, but the patterns of predictors were broadly similar.

\section{TABLE 3}

Model 2 includes cognitive scores at age five. This tells us the extent to which the differentials apparent at age 42 had already been accounted for by cognitive attainment at the start of primary school. Cognition at five is clearly a powerful predictor of class at 42 , but the influence of parental education and income is only somewhat attenuated in this model. The advantage due to having a university graduate parent is reduced from an odds ratio of 2.8 to 2.4, for example.

Model 3 introduces cognitive scores at age ten, towards the end of primary school. Cognition at ten is the most important predictor of class at 42 in this model, and, as we might expect, fully accounts for the influence of cognition at five. A one standard deviation increase in cognitive scores at ten nearly doubles the odds of being in social class 1 at age 42 . The influence of family income, social class and parental education are substantially attenuated in this model. In other words, much of the origins-destinations link has already been mediated by cognition at age ten, before cohort members have gone to secondary school or taken any formal qualifications.

In model 4, we add the type of secondary school attended. Men who had attended non-Tatler private schools had 1.7 times the odds of being in the top social class at 42 compared to those who had attended comprehensives. The coefficient for Tatler schools was positive but did not 
reach statistical significance. There was no statistically significant grammar school advantage, or secondary modern disadvantage. The differentials according to social origins are barely changed in this model, suggesting that secondary school type was not as important a vehicle of social advantage as is commonly supposed. Given the current policy interest in the idea that selective schools may promote social mobility for less privileged children ${ }^{\text {iv }}$, we tested for statistical interactions between childhood social class and secondary school type, but we found no pattern of differential advantage by social origins.

Model 5 introduces cognitive scores at 16 and school level qualifications at 16 and 18. Cognitive scores at 16 are positively associated with social class in mid-life. People with a maths $\mathrm{O}$ level had 1.7 times the odds of being in class 1 at age 42 compared to those without this qualification. A level performance was also an important predictor of class attainment. However, cognition at age ten retains its predictive power, as does having a university graduate parent.

Model 6 includes degree level qualifications. Compared to no degree, a non-elite humanities degree is associated with 1.8 times the odds of being in the top social class. An individual with an elite LEM degree has seven times the odds of being in a top job compared to their equivalent without a degree. STEM and LEM degrees, from both elite and non-elite universities, are associated with a substantial and statistically significant greater advantage than OSSAH degrees from either type of university. The influence of parental education is fully accounted for in this model, leaving no direct social origins effects. Neither were parents' social class, education and income jointly significant $(\mathrm{F}=0.962)$. Cognitive scores at age ten and maths $\mathrm{O}$ level at age 16 predict social class position at age 42, even when degree 
level qualifications are taken into account. The relative position of women compared to men remains unchanged: they have half the odds of being in the top social class.

\section{Structural Equation Model (SEM)}

We present a Structural Equation Model in order to formally estimate direct (not mediated) and indirect effects of social origins on destinations in mid-life (figure 1). The analysis essentially mirrors the logistic regression analysis described above, but the SEM approach means that some variables are treated somewhat differently. Childhood socio-economic status is treated as a latent variable, based on parental education, social class and income. This reduces the dimensionality of the data, allowing for a simpler presentation. Qualifications at 42 combine degree status (treated as a continuous variable based on the hierarchy of degrees implied by our regression analysis), the highest level of qualification achieved (NVQ1-6) and qualifications at 16 and 18 . The SEM is estimated with probit link functions for binary variables that assume a linear system of associations on the latent variables that are invoked by the probit model (MacKinnon et al. 2007). We opted for this approach as it is flexible in the presence of many mediators and does not assume the nonexistence of exposure induced mediator - outcome confounders. However, this approach may be sensitive to violations of the assumed linear system, but sensitivity analysis with Natural Indirect and Direct Effects (Muthen and Asparouhov 2015; VanderWeele 2015) which make alternative assumptions but are appropriate for nonlinear systems returns similar results (available on request).

[Figure 1 here]

The model fit is good according to the goodness of fit indicators: Root Mean Square Error of Approximation - RMSEA=0.04, Comparative Fit Index - CFI=0.97 and Tucker Lewis Index - 
TLI $=0.95$. Values $<0.06$ for RMSEA, and $>0.95$ for the CFI and TLI (Fan and Sivo 2007; Hu and Bentler 1999).

Figure 1 shows that childhood socioeconomic status directly affects cognitive scores at five and ten, attendance at a private school, and qualifications achieved by 42 . SES predicts qualifications via cognitive scores at five and ten, but also directly, i.e. there is an SES differential in qualifications over and above the differential in cognitive scores. SES indirectly affects social class at 42 via all of these factors, of which only cognition at ten and qualifications at 42 have a direct influence on class at 42 . However, as in the multivariable logistic regressions, we find no direct (i.e. unmediated) effect of childhood socioeconomic status on class at 42 . We confirm that the female disadvantage is direct, and unaffected by any of the education variables.

\section{Discussion}

We find that the influence of childhood social advantage is entirely channelled by education: we do not find evidence for a direct link between social origins and top class destinations. The fact that we find no direct link between origins and elite destinations once individual educational attainment is accounted for contrasts with previous work. Our findings run counter to the view that the effect of education on class destinations is actually weakening due to educational expansion (Goldthorpe 2013), and instead support the view suggested by the Effectively Maintained Inequality (EMI) hypothesis that it is increasingly important to take into account differentials within higher qualification levels, as educational expansion has made these more salient at the higher end of the class structure.

A key strength of our study is the comprehensiveness of our measures of cognitive and educational attainment. We find that cognitive performance is a powerful direct predictor of occupational outcomes, which is perhaps surprising in our 'credentialist' society (Collins 
1979). Our findings point to the conclusion that the conventional approach to educational attainment as a single variable using the highest qualification on a standard scale will lead to measurement error and residual confounding, potentially exaggerating the role of noneducational factors, including the direct role of social origins. It is therefore desirable to take into account a full picture of educational attainment before seeking alternative explanations for any residual origins-destinations link, such as invoking social class differences in 'soft skills' and social networks (Goldthorpe 2013). This does not however imply that noncognitive factors are not potentially important in their own right, although an investigation of such additional pathways is beyond the scope of the current paper. A limitation of the current study is that we do not consider income differentials within occupational classes (Crawford et al. 2016; Crawford and Vignoles 2014; Kim and Sakamoto 2008; Laurison and Friedman 2016; Macmillan, Tyler and Vignoles 2015). We also do not examine access to positions lower down the class structure, where a very different refinement of the conventional approach to qualifications may be required, with particular challenges in the UK case, where there is no single system of vocational qualifications. This may be a fruitful avenue for future research.

It is striking that, while social class differences in top class occupational destinations were entirely attributable to education, the occupational gap between men and women was not accounted for by any aspect of education, including differences in subject specialisms.

Our life course approach reveals that there is no single decisive stage of the educational career that accounts for access to the top social class in mid-life. Our analysis supports the view that cognitive scores at the start of formal schooling are important, but we find that cognitive progress between age five and ten accounts for an even greater portion of the 
origins-to-destinations link. This link is further chipped away by qualifications at 16 and 18 , and finally by degree level qualifications. The type of secondary school attended matters on an individual level, but does very little to explain the link between social origins and adult top class destinations at the population level. In policy terms, our analysis confirms the importance of the pre-school years, and emphasises the salience of the primary school years. However, our findings also suggest that there is scope for intervention with a view to promoting social mobility throughout the educational career.

While private schools appeared to make a difference for their pupils, their role in the overall picture of social reproduction into occupations at the top of the social class distribution is limited by the very small proportion of pupils who attended them. We found no grammar school effect, and no evidence that the gains linked to a private or grammar education varied according to social origins, a view suggested by those who believe that selective schooling is vital to the social mobility chances of working class youth.

Overall, a university degree was a powerful predictor of increased odds of reaching the top, but there were also clear differentials between types of degrees. Graduates with STEM and LEM degrees were substantially more likely to reach class 1 than those with OSSAH degrees. As well as differences in the marketability of different degrees, this may also reflect differences in the prior career aspirations of students going into different fields. The status of the university attended appeared to be less important than the subject of the degree.

Our results may seem to present a rosy picture of broadly 'meritocratic' access to top jobs. We should note that, in common with past work in this area, the majority of the variance is 
actually unexplained, and must be due to unmeasured factors. The extent to which these unmeasured pathways may be characterised as 'meritocratic' is unknown empirically and debatable philosophically (Payne 2017; Swift 2004). Even if we regard the pathway from educational success to occupational attainment as 'meritocratic', the parental resources and access to high quality education which provide huge advantages in developing cognitive skill and achieving educational credentials are not evenly distributed. Our analysis shows that the link between social origins and top class destinations is accounted for by the gradual accumulation of cognitive and educational advantage during schooling and further and higher education. As parents with the necessary resources invest heavily in their children's education (Putnam 2015; Reardon 2011), ascriptive forces may increasingly be expressed as 'merit'.

Finally, a limitation of our study is that it considers only one generation, and focusses only on occupational social class destinations. Given the changing nature of inequalities, with younger generations increasingly disadvantaged in terms of wealth (Cribb, Hood and Joyce 2015), our future work will examine generational change and differences in the nature of the intergenerational transmission of advantage according to social class, income and wealth.

Acknowledgements: This research was funded by ESRC award ES/K007238/1

Many thanks are due to the BCS70 cohort members, who have generously given up their time over many years to generate the data that we use here. Thanks also to three anonymous reviewers for their comments. 
Bibliography

Bernardi, Fabrizio, and Gabriele Ballarino. 2016. Education, occupation and social origin: A comparative analysis of the transmission of socio-economic inequalities: Edward Elgar Publishing.

Blanden, J., P. Gregg, and L. Macmillan. 2007. "Accounting for Intergenerational Income Persistence: Noncognitive Skills, Ability and Education." The Economic Journal 117(519):43-60.

Blanden, Jo, and Stephen Machin. 2017. "Home ownership and social mobility." CEP Discussion Paper 1466.

Boliver, V., and A. Swift. 2011. "Do comprehensive schools reduce social mobility." British Journal of Sociology 62(1):89-110.

Boliver, Vikki. 2013. "How fair is access to more prestigious UK universities?" British Journal of Sociology 64(2):344-64.

Bourdieu, Pierre, and Jean Claude Passeron. [1977] 1990. Reproduction in education, society and culture. London; Beverly Hills: Sage Publications.

Bowles, Samuel, and Herbert Gintis. 1976. Schooling in capitalist America : educational reform and the contradictions of economic life. New York: Basic Books.

Breen, R. (Ed.). 2004. Social Mobility in Europe. Oxford: Oxford University Press.

Breen, R., and J. H. Goldthorpe. 2001. "Class, mobility and merit - The experience of two British birth cohorts." European Sociological Review 17(2):81-101.

Brewer, Dominic J, Eric R Eide, and Ronald G Ehrenberg. 1999. "Does it pay to attend an elite private college? Cross-cohort evidence on the effects of college type on earnings." Journal of Human Resources:104-23.

Bukodi, E., and J. Goldthorpe. 2012. "Decomposing 'Social Origins': The Effects of Parents' Class, Status, and Education on the Educational Attainment of Their Children." European Sociological Review Advance Online Access.

Bukodi, E., J. Goldthorpe, B. Halpin, and L. Waller. 2016 "Is Education Now Class Destiny? Class Histories across Three British Birth Cohorts." European Sociological Review 32(6):835-49.

Bukodi, Erzsébet, and John H Goldthorpe. 2011. "Class Origins, Education and Occupational Attainment in Britain: Secular Trends or Cohort-Specific Effects?" European Societies 13(3):347-75.

Bukodi, Erzsébet, John H Goldthorpe, Lorraine Waller, and Jouni Kuha. 2015. "The mobility problem in Britain: new findings from the analysis of birth cohort data." British Journal of Sociology 66(1):93-117.

Burgess, S., M. Dickson, and L. Macmillan. 2014. "Selective schooling systems increase inequality." Department of Quantitative Social Science Working Paper no. 14-09.

Chamberlain, R., G. Chamberlain, B. Wowlett, and A. Claireaux. 1975. British Births 1970: Volume 1, The first week of life. London: William Heinemann Medical Books Ltd.

Chevalier, Arnoud, and Gavan Conlon. 2003. "Does it pay to attend a prestigious university?" Pp. 35: Centre for the Economics of Education, London School of Economics and Political Sciences.

Collins, R. 1979. The credential society : an historical sociology of education and stratification. New York: Academic Press.

Crawford, Claire, Paul Gregg, Lindsey Macmillan, Anna Vignoles, and Gill Wyness. 2016. "Higher education, career opportunities, and intergenerational inequality." Oxford Review of Economic Policy 32(4):553-75. 
Crawford, Claire, and Anna Vignoles. 2014. "Heterogeneity in graduate earnings by socioeconomic background." Institute for Fiscal Studies, London. Available from: http://www. ifs. org. uk/publications/741 9.

Cribb, J., A. Hood, and R. Joyce. 2015. Living Standards: Recent Trends and Future Challenges. London: IFS.

Croxford, Linda, and David Raffe. 2015. "The iron law of hierarchy? Institutional differentiation in UK higher education." Studies in Higher Education 40(9):1625-40.

Dearden, L, J. Ferri, and C. Meghir. 2002. "The Effect of School Quality on Educational Attainment and Wages." Review of Economics and Statistics 84:1-20.

Deterding, Nicole M, and David S Pedulla. 2016. "Educational Authority in the 'Open Door' Marketplace: Labor Market Consequences of For-profit, Nonprofit, and Fictional Educational Credentials." Sociology of Education 89(3):155-70.

Devine, Fiona, and Yaojun Li. 2013. "The changing relationship between origins, education and destinations in the 1990s and 2000s." British Journal of Sociology of Education 34(5-6):766-91.

Duncan, Greg J, and Katherine Magnuson. 2011. "The nature and impact of early achievement skills, attention skills, and behavior problems." Pp. 47-70 in Whither Opportunity? Rising Inequality and the Uncertain Life Chances of Low-Income Children, edited by R. Murnane and G. Duncan. New York: Russell Sage Foundation.

Elliott, J., and P. Shepherd. 2006. "Cohort Profile: 1970 British birth cohort (BCS70)." International Journal of Epidemiology 35(4):836-43.

Fan, Xitao, and Stephen A. Sivo. 2007. "Sensitivity of Fit Indices to Model Misspecification and Model Types." Multivariate Behavioral Research 42(3):509-29.

Farkas, George, and Kurt Beron. 2004. "The detailed age trajectory of oral vocabulary knowledge: Differences by class and race." Social Science Research 33(3):464-97.

Feinstein, L. 2003. "Inequality in the Early Cognitive Development of British Children in the 1970 Cohort." Economica 70(1):73-97.

Feinstein, L., and J. Symons. 1999. "Attainment in secondary school." Oxford Economic Papers 51:300-21.

Gerber, Theodore P., and Sin Yi Cheung. 2008. "Horizontal stratification in postsecondary education: forms, explanations, and implications." Annual Review of Sociology 34:299-318.

Gillard, D. 2011. Education in England: a brief history: www.educationengland.org.uk/history

Goldthorpe, J., and A. McKnight. 2006. "The economic basis of social class." in Mobility and Inequality: Frontiers of research from sociology and economics, edited by S. Morgan, D.B. Grusky, and G.S. Fields. Stanford: Stanford University Press.

Goldthorpe, J.H. 1997. " The 'Goldthorpe' class schema: some observations on conceptual and operational issues in relation to the ESRC review of government social classifications." in Constructing Classes: Towards a New Social Classification for the $U K$, edited by D. Rose and K. O'Reilly. Swindon: ESRC/ONS.

Goldthorpe, John H. 2013. "Understanding-and misunderstanding-social mobility in Britain: the entry of the economists, the confusion of politicians and the limits of educational policy." Journal of Social Policy 42(03):431-50.

Green, F., S. Machin, R. Murphy, and Y. Zhu. 2012. "The changing economic advantage from private schools." Economica 79(316):658-79.

Green, Francis, Samantha Parsons, Alice Sullivan, and Richard Wiggins. In press. "Dreaming Big: Self-Evaluations, Aspirations, High-Valued Social Networks, and the PrivateSchool Earnings Premium." Cambridge Journal of Economics. 
Greenland, Sander, James M Robins, and Judea Pearl. 1999. "Confounding and collapsibility in causal inference." Statistical Science:29-46.

Gutierrez, Oscar Marcenaro, John Micklewright, and Anna Vignoles. 2015. "Social mobility, parental help, and the importance of networks: evidence for Britain." Longitudinal and Life Course Studies 6(2):190-211.

Halsey, A., A. Heath, and J. Ridge. 1980. Origins And Destinations. Family, Class and Education in Modern Britain. Oxford: Clarendon Press.

$\mathrm{Hu}$, Li-tze, and Peter M. Bentler. 1999. "Cutoff criteria for fit indexes in covariance structure analysis: Conventional criteria versus new alternatives." Structural Equation Modeling: A Multidisciplinary Journal 6(1):1-55.

Iannelli, Cristina. 2013. "The role of the school curriculum in social mobility." British Journal of Sociology of Education 34(5-6):907-28.

Jackson, M., R. Luijjkx, R. Pollak, L-A. Vallet, and H. Van de Werfhorst. 2008. "Educational fields of study and the intergenerational mobiility process in comparative perspective." International Journal of Comparative Sociology 49(4-5):369-88.

Jackson, Michelle. 2007. "How far merit selection? Social stratification and the labour market." British Journal of Sociology 58(3):367-90.

Jencks, C. 1972. Inequality: A Reassessment of the Effect of Family and Schooling in America. New York: Basic Books.

Jencks, Christopher. 1979. Who gets ahead? : The determinants of economic success in America. New York: Basic Books.

Joshi, H., G. Makepeace, and P. Dolton. 2007. "More or less unequal? Evidence on the pay of men and women from the British Birth Cohort Studies." Gender, Work and Organization 14(1):37-51.

Kim, ChangHwan, and Arthur Sakamoto. 2008. "The rise of intra-occupational wage inequality in the United States, 1983 to 2002." American Sociological Review 73(1):129-57.

Kim, ChangHwan, Christopher R Tamborini, and Arthur Sakamoto. 2015. "Field of Study in College and Lifetime Earnings in the United States." Sociology of Education 88(4):320-39.

Kirby, P. 2016. "Leading people 2016: The educational backgrounds of the UK professional elite." London, Sutton Trust.

Laurison, Daniel, and Sam Friedman. 2016. "The class pay gap in higher professional and managerial occupations." American Sociological Review 81(4):668-95.

Little, R. J. A., and D. B. Rubin. 2002. Statistical Analysis with Missing Data Chichester: Willey.

Lucas, Samuel R. 2001. "Effectively Maintained Inequality: Education, Transitions, Track Mobility, and Social Background Effects." American Journal of Sociology 106:164290.

Ma, Yingyi, and Gokhan Savas. 2014. "Which Is More Consequential: Fields of Study or Institutional Selectivity?" The Review of Higher Education 37(2):221-47.

MacKinnon, D.P., C.M. Lockwood, C.H. Brown, W. Wang, and J.M. Hoffman. 2007. "The intermediate endpoint effect in logistic and probit regression." Clinical Trials 4(5):499-513.

Macmillan, Lindsey, Claire Tyler, and Anna Vignoles. 2015. "Who gets the top jobs? The role of family background and networks in recent graduates' access to high-status professions." Journal of Social Policy 44(03):487-515.

Marks, Gary N. 2013. Education, social background and cognitive ability: The decline of the social: Routledge. 
McKnight, Abigail. 2015. "Downward mobility, opportunity hoarding and the 'glass floor'." London: Social Mobility and Child Poverty Commission.

Mostafa, Tarek, and R.D. Wiggins. 2015. "The impact of attrition and non-response in birth cohort studies: a need to incorporate missingness strategies." Longitudinal and Life Course Studies 6(2):131-46.

Muthen, Bengt, and Tihomir Asparouhov. 2015. "Causal Effects in Mediation Modeling: An Introduction With Applications to Latent Variables." Structural Equation Modeling-a Multidisciplinary Journal 22(1):12-23.

O Leary, Nigel C., and Peter J. Sloane. 2005. "The return to a university education in Great Britain." National Institute Economic Review 193(1):75-89.

Parsons, S. 2014. "Childhood cognition in the 1970 British Cohort Study." CLS Data Note.

Patrignani, Pietro, and Gavan Conlon. 2011. "The long term effect of vocational qualifications on labour market outcomes." BIS Research Paper 45.

Payne, Geoff. 2017. The New Social Mobility: How the Politicians Got it Wrong. Bristol: Policy Press.

Piketty, Thomas, Arthur Goldhammer, and LJ Ganser. 2014. Capital in the twenty-first century: Harvard University Press.

Prandy, K. 1990. "The revised Cambridge scale of occupations." Sociology 24(629-655).

Putnam, Robert D. 2015. Our kids: The American dream in crisis. New York: Simon and Schuster.

Rae, John. 1981. The public school revolution: Britain's independent schools, 1964-1979. London: Faber \& Faber

Raftery, A. E., and M. Hout. 1993. "Maximally Maintained Inequality - Expansion, Reform, and Opportunity in Irish Education, 1921-75." Sociology of Education 66(1):41-62.

Reardon, Sean F. 2011. "The widening academic achievement gap between the rich and the poor: New evidence and possible explanations." Pp. 91-116 in Whither Opportunity? Rising Inequality and the Uncertain Life Chances of Low-Income Children, edited by R. Murnane and G. Duncan. New York: Russell Sage Foundation.

Rose, D., and K. O'Reilly. 1998. "The Economic and Social Research Council review of government social classifications." Journal of the Royal Statistical Society Series A: Statistics in Society 161(1):2-4.

Saunders, Peter. 2010. Social mobility myths: Civitas.

Savage, Mike, Fiona Devine, Niall Cunningham, Mark Taylor, Yaojun Li, Johs Hjellbrekke, Brigitte Le Roux, Sam Friedman, and Andrew Miles. 2013. "A new model of social class? Findings from the BBC's Great British Class Survey Experiment." Sociology 47(2):219-50.

Schafer, J.L. 1997. Analysis of Incomplete Multivariate Data. London: Chapman and Hall.

Social Mobility and Child Poverty Commission. 2015. "Bridging the social divide: Report on making social mobility and child poverty core business for the next parliament." London.

Sullivan, A., and A. Heath. 2003. "Intakes and Examination Results at State and Private Schools." Pp. 77-104 in British Private Schools: research on policy and practice, edited by G. Walford. London: Woburn Press.

Sullivan, A., S. Ketende, and H. Joshi. 2013. "Social Class and Inequalities in Early Cognitive Scores." Sociology 47(6):1187-206.

Sullivan, Alice, and Matthew Brown. 2015. "Vocabulary from adolescence to middle age." Longitudinal and Life Course Studies 6(2):173-89.

Sullivan, Alice, Samantha Parsons, Richard D Wiggins, Anthony F Heath, and Francis Green. 2014. "Social origins, school type and higher education destinations." Oxford Review of Education 40(6):739-63. 
Swift, Adam. 2004. "Would perfect mobility be perfect?" European Sociological Review 20(1):1-11.

Torche, Florencia. 2011. "Is a College Degree Still the Great Equalizer? Intergenerational Mobility across Levels of Schooling in the United States." American Journal of Sociology 117(3):763-807.

VanderWeele, Tyler. 2015. Explanation in causal inference: methods for mediation and interaction: Oxford University Press.

Wakeling, Paul, and Mike Savage. 2015a. "Elite Universities, Elite Schooling and Reproduction in Britain." Pp. 169-84 in World Yearbook of Education 2015: Elites, Privilege and Excellence: The National and Global Redefinition of Educational Advantage, edited by Stephen Ball, Agnès van Zanten, and Brigitte Darchy-Koechlin. London: Routledge.

- 2015b. "Entry to elite positions and the stratification of higher education in Britain." The Sociological Review 63(2):290-320.

Walker, Ian, and Yu Zhu. 2011. "Differences by degree: Evidence of the net financial rates of return to undergraduate study for England and Wales." Economics of Education Review 30(6):1177-86.

—. 2013. "The impact of university degrees on the lifecycle of earnings: some further analysis." BIS Research Paper 112.

\footnotetext{
i 'Tatler Schools Guide 2014' http://www.tatler.com/guides/schools-guide/2014

ii The Russell Group was established in 1994. Its current members are the universities of: Birmingham, Bristol, Cambridge, Cardiff, Durham, Edinburgh, Exeter, Glasgow, Imperial College London, King's College London, Leeds, Liverpool, LSE, Manchester, Newcastle, Nottingham, Oxford, Queen Mary University of London, Queen's Belfast, Sheffield, Southampton, University College London, Warwick, York.

${ }^{\text {iii }}$ We also consulted data on university points entry from 1989-90 and 2011, and included two additional universities that have consistently featured in the top 30 most selective institutions: University of Bath and St Andrews.

iv Prime Minister Theresa May outlined plans to create a 'truly meritocratic Britain' by introducing more grammar schools in a speech on $9^{\text {th }}$ September 2016.
} 
Table 1: Percentage in NS-SEC 1 by social origins and educational characteristics

\begin{tabular}{|c|c|c|c|c|c|}
\hline & $\begin{array}{c}\text { Sample } \\
\text { characte } \\
\text { ristics \% } \\
\end{array}$ & $\begin{array}{r}\text { Original } \\
N\end{array}$ & $\begin{array}{r}\% \\
\text { missing }\end{array}$ & $\begin{array}{c}\% \text { of each } \\
\text { group in NS- } \\
\text { SEC } 1\end{array}$ & $\begin{array}{c}\text { Composition } \\
\text { of NSSEC class } \\
1\end{array}$ \\
\hline Percentage in NS-SEC 1 & & 7102 & 0 & 15.0 & \\
\hline Male & 49.7 & 3529 & & 19.3 & 63.9 \\
\hline Female & 50.3 & 3573 & & 10.8 & 36.1 \\
\hline Parent qualifications (5) & & 6264 & 11.8 & & \\
\hline None & 33.2 & & & 8.8 & 19.5 \\
\hline Vocational & 15.9 & & & 11.9 & 12.6 \\
\hline O Levels & 23.3 & & & 15.3 & 23.7 \\
\hline A Levels & 10.7 & & & 17.6 & 12.5 \\
\hline Degree or higher & 16.9 & & & 28.2 & 31.6 \\
\hline Social class (RG) (birth): & & 7102 & 0 & & \\
\hline IV/V semi and unskilled & 14.8 & & & 9.7 & 9.8 \\
\hline III skilled manual & 29.9 & & & 10.4 & 20.6 \\
\hline III skilled non manual & 30.9 & & & 15.8 & 32.2 \\
\hline I/II professional/managerial & 24.5 & & & 23.0 & 37.3 \\
\hline Income (10): & & 5897 & 17.0 & & \\
\hline$<£ 35$ & 1.3 & & & 9.5 & 0.8 \\
\hline$£ 36-£ 49$ & 4.6 & & & 8.3 & 2.5 \\
\hline$£ 50-£ 99$ & 25.5 & & & 11.1 & 18.9 \\
\hline f100- f149 & 35.9 & & & 13.7 & 32.6 \\
\hline$£ 150-£ 199$ & 19.2 & & & 17.9 & 22.9 \\
\hline$£ 200-£ 249$ & 7.6 & & & 20.2 & 10.2 \\
\hline f250+ & 5.9 & & & 30.2 & 12.0 \\
\hline $\begin{array}{l}\text { Cognitive score (5) } \\
\text { (range: }-3.94-5.02 \text { ) } \\
\end{array}$ & & 5615 & 20.9 & & \\
\hline Lowest quartile & 24.5 & & & 8.1 & 13.1 \\
\hline $2^{\text {nd }}$ quartile & 24.9 & & & 13.6 & 22.5 \\
\hline $3^{\text {rd }}$ quartile & 25.2 & & & 15.7 & 26.3 \\
\hline Highest quartile & 25.4 & & & 22.5 & 38.1 \\
\hline $\begin{array}{l}\text { Cognitive score }(10) \\
\text { (range: }-4.11-3.25)\end{array}$ & & 5632 & 20.7 & & \\
\hline Lowest quartile & 24.2 & & & 5.3 & 8.4 \\
\hline $2^{\text {nd }}$ quartile & 24.8 & & & 9.6 & 16.0 \\
\hline $3^{\text {rd }}$ quartile & 25.2 & & & 16.1 & 27.0 \\
\hline Highest quartile & 25.8 & & & 28.3 & 48.6 \\
\hline Secondary school type & & 7102 & 0 & & \\
\hline Comprehensive & 80.9 & & & 13.6 & 73.5 \\
\hline Secondary Modern & 8.6 & & & 9.0 & 5.2 \\
\hline Grammar & 4.4 & & & 23.6 & 6.8 \\
\hline Private (all schools) & 6.1 & & & 35.6 & 14.5 \\
\hline Private (non-Tatler) & 4.7 & & & 34.7 & 10.9 \\
\hline Private (Tatler) & 1.4 & & & 38.8 & 3.6 \\
\hline $\begin{array}{l}\text { Cognitive score }(16) \\
\text { (range: }-5.00-2.45 \text { ) }\end{array}$ & & 1484 & 79.1 & & \\
\hline Lowest quartile & 24.3 & & & 6.3 & 10.2 \\
\hline $2^{\text {nd }}$ quartile & 24.8 & & & 10.4 & 17.1 \\
\hline $3^{\text {rd }}$ quartile & 25.2 & & & 16.1 & 22.9 \\
\hline Highest quartile & 25.9 & & & 26.6 & 44.8 \\
\hline $\begin{array}{l}\text { Public exams score (16) } \\
\text { (range: }-1.24-4.61 \text { ) }\end{array}$ & & 3052 & 57.0 & & \\
\hline Lowest quartile & 22.1 & & & 8.8 & 12.9 \\
\hline
\end{tabular}




\begin{tabular}{|c|c|c|c|c|c|}
\hline & $\begin{array}{c}\text { Sample } \\
\text { characte } \\
\text { ristics \% }\end{array}$ & $\begin{array}{r}\text { Original } \\
N\end{array}$ & $\begin{array}{r}\% \\
\text { missing }\end{array}$ & $\begin{array}{c}\% \text { of each } \\
\text { group in NS- } \\
\text { SEC } 1\end{array}$ & $\begin{array}{c}\text { Composition } \\
\text { of NSSEC class } \\
1\end{array}$ \\
\hline $2^{\text {nd }}$ quartile & 26.4 & & & 10.7 & 18.9 \\
\hline $3^{\text {rd }}$ quartile & 25.5 & & & 13.2 & 22.3 \\
\hline Highest quartile & 26.0 & & & 26.5 & 45.9 \\
\hline English O Level/CSE (16) & & 6662 & 6.2 & & \\
\hline No & 56.7 & & & 9.0 & 34.0 \\
\hline Grade A-C & 43.3 & & & 22.9 & 66.0 \\
\hline Maths: O Level/CSE (16) & & 6664 & 6.2 & & \\
\hline No & 63.7 & & & 8.4 & 35.4 \\
\hline Grade A-C & 36.3 & & & 26.7 & 64.6 \\
\hline A levels (by age 20) & & 7102 & 0 & & \\
\hline None & 81.6 & & & 11.2 & 61.0 \\
\hline D-E Grade & 3.6 & & & 24.4 & 5.8 \\
\hline 1-2 A-C Grade & 8.3 & & & 25.4 & 14.1 \\
\hline $3+\mathrm{A}-\mathrm{C}$ Grade & 6.5 & & & 44.0 & 19.1 \\
\hline Degree status & & 7102 & 0 & & \\
\hline No degree & 76.3 & & & 8.9 & 45.3 \\
\hline OSSAH, Ordinary univ & 8.4 & & & 20.8 & 11.7 \\
\hline OSSAH, Elite univ & 3.6 & & & 30.0 & 7.1 \\
\hline STEM, Ordinary univ & 4.7 & & & 41.3 & 12.8 \\
\hline STEM, Elite univ & 2.6 & & & 57.0 & 9.9 \\
\hline LEM, Ordinary univ & 3.4 & & & 41.3 & 9.6 \\
\hline LEM, Elite univ & 0.9 & & & 58.5 & 3.6 \\
\hline $\mathrm{N}(100 \%)$ & 7102 & & & & 1067 \\
\hline
\end{tabular}

Imputed means, original $n$ 
Table 2: Correlation coefficients between cognitive and attainment scores

\begin{tabular}{|c|c|c|c|c|c|c|c|c|}
\hline & $\begin{array}{l}\text { Cognitive } \\
5\end{array}$ & $\begin{array}{l}\text { Cognitive } \\
10\end{array}$ & $\begin{array}{l}\text { Cognitive } \\
16\end{array}$ & $\begin{array}{l}\text { Exam } \\
\text { score } \\
16\end{array}$ & $\begin{array}{l}\text { Maths } \\
\text { A-C }\end{array}$ & $\begin{array}{l}\text { English } \\
\text { A-C }\end{array}$ & $\begin{array}{l}\text { A } \\
\text { Levels }\end{array}$ & Elite/Degree \\
\hline Cognitive 5 & 1 & & & & & & & \\
\hline Cognitive 10 & $.56(.01)$ & 1 & & & & & & \\
\hline Cognitive 16 & $.46(.02)$ & $.68(.02)$ & 1 & & & & & \\
\hline $\begin{array}{l}\text { Exam score } \\
16\end{array}$ & $.35(.01)$ & $.51(.01)$ & $.51(.01)$ & 1 & & & & \\
\hline Maths A-C & $.31(.02)$ & $.46(.02)$ & $.47(.03)$ & $\begin{array}{l}.60 \\
(.02)\end{array}$ & 1 & & & \\
\hline English A-C & $.32(.02)$ & $.47(.02)$ & $.48(.03)$ & $\begin{array}{l}.62 \\
(.02)\end{array}$ & $\begin{array}{l}.61 \\
(.01)\end{array}$ & 1 & & \\
\hline A Levels & $.28(.01)$ & $.41(.01)$ & $.37(.01)$ & $\begin{array}{l}.45 \\
(.01)\end{array}$ & $\begin{array}{l}.45 \\
(.01)\end{array}$ & $.42(.01)$ & 1 & \\
\hline Elite/Degree & $.29(.02)$ & $.41(.02)$ & $.37(.02)$ & $\begin{array}{l}.41 \\
(.02)\end{array}$ & $\begin{array}{l}.41 \\
(.01)\end{array}$ & $.39(.01)$ & $\begin{array}{l}.59 \\
(.01)\end{array}$ & 1 \\
\hline
\end{tabular}


Table 3: Binary logistic regression analysis of attainment of a top social class position

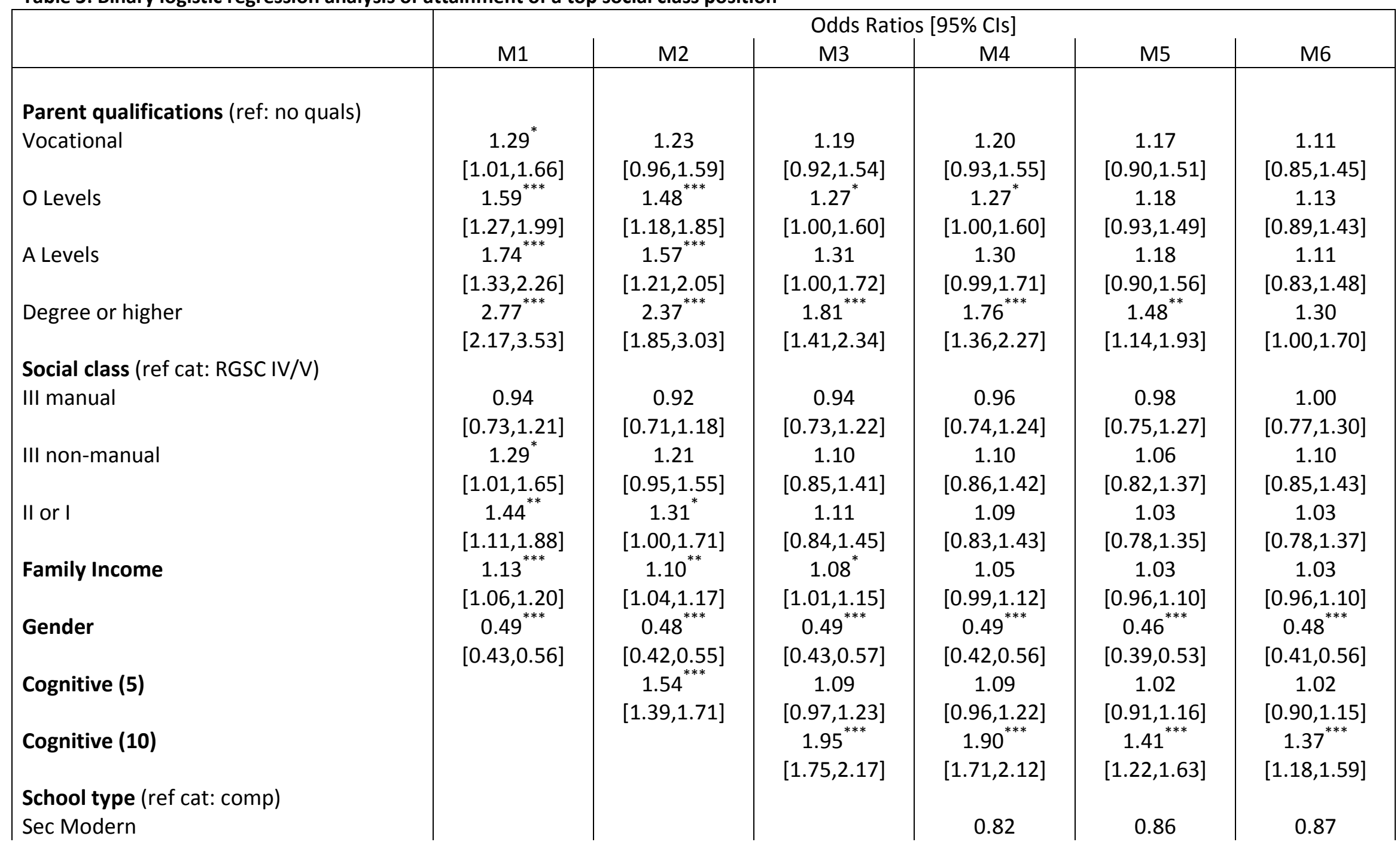




\begin{tabular}{|c|c|c|c|c|c|c|}
\hline & & & Odds & [95\% Cls] & & \\
\hline & M1 & $\mathrm{M} 2$ & M3 & M4 & M5 & M6 \\
\hline & & & & {$[0.61,1.11]$} & {$[0.64,1.16]$} & {$[0.64,1.19]$} \\
\hline Grammar & & & & 1.10 & 0.94 & 0.97 \\
\hline & & & & {$[0.82,1.48]$} & {$[0.70,1.27]$} & {$[0.72,1.33]$} \\
\hline Private-Other & & & & $1.72^{* * *}$ & $1.49^{* *}$ & $1.34^{*}$ \\
\hline & & & & {$[1.32,2.24]$} & {$[1.14,1.96]$} & {$[1.01,1.78]$} \\
\hline Private - Tatler & & & & 1.26 & 1.04 & 0.97 \\
\hline & & & & {$[0.80,1.99]$} & {$[0.65,1.65]$} & {$[0.60,1.56]$} \\
\hline Cognitive (16) & & & & & $1.18^{*}$ & 1.10 \\
\hline & & & & & {$[1.00,1.40]$} & {$[0.93,1.29]$} \\
\hline Exam performance (16) & & & & & & \\
\hline Exam Score & & & & & 1.02 & 0.99 \\
\hline & & & & & {$[0.92,1.12]$} & {$[0.90,1.09]$} \\
\hline English A-C & & & & & 1.08 & 1.02 \\
\hline & & & & & {$[0.88,1.33]$} & {$[0.82,1.26]$} \\
\hline Mathematics A-C & & & & & $1.74^{* * *}$ & $1.60^{* * *}$ \\
\hline & & & & & {$[1.42,2.14]$} & {$[1.30,1.98]$} \\
\hline A Levels (18) (ref cat: none) & & & & & & \\
\hline D-E grades & & & & & 1.23 & 0.96 \\
\hline & & & & & {$[0.90,1.70]$} & {$[0.69,1.35]$} \\
\hline 1-2 A-C grades & & & & & $1.31^{*}$ & 0.98 \\
\hline & & & & & {$[1.04,1.65]$} & {$[0.76,1.25]$} \\
\hline $3+A-C$ grades & & & & & $2.02^{* * *}$ & 1.15 \\
\hline & & & & & {$[1.58,2.58]$} & {$[0.87,1.51]$} \\
\hline Higher Ed (ref cat: No degree) & & & & & & \\
\hline OSSAH - Non Elite univ & & & & & & $1.76^{* * *}$ \\
\hline & & & & & & {$[1.37,2.26]$} \\
\hline OSSAH - Elite univ & & & & & & $1.97^{* * *}$ \\
\hline & & & & & & {$[1.41,2.77]$} \\
\hline
\end{tabular}




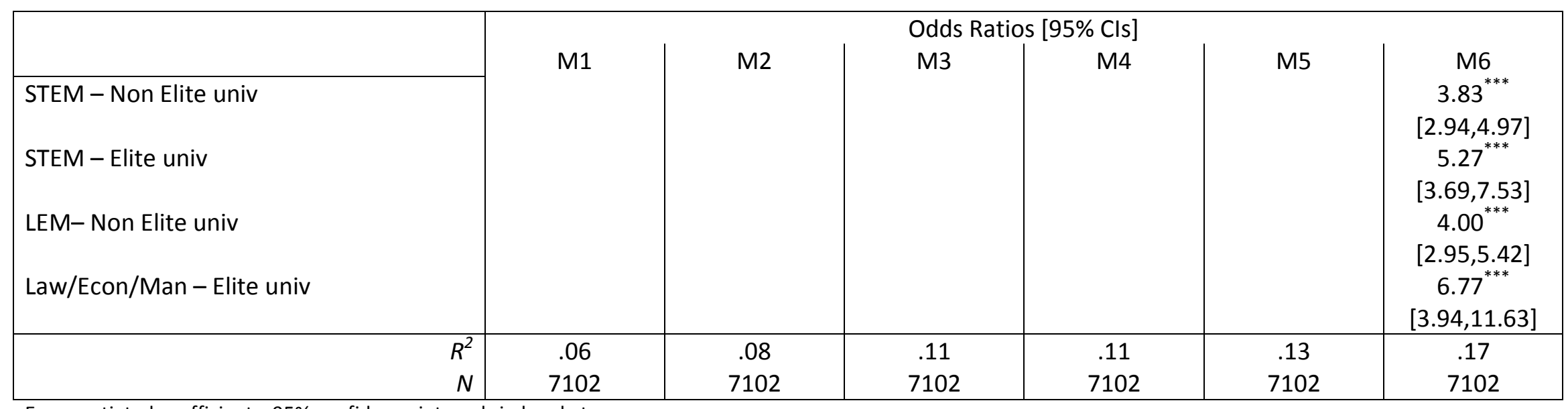

Exponentiated coefficients; $95 \%$ confidence intervals in brackets
${ }^{*}<<0.05,{ }^{* *} p<0.01,{ }^{* * *} p<0.001$ 


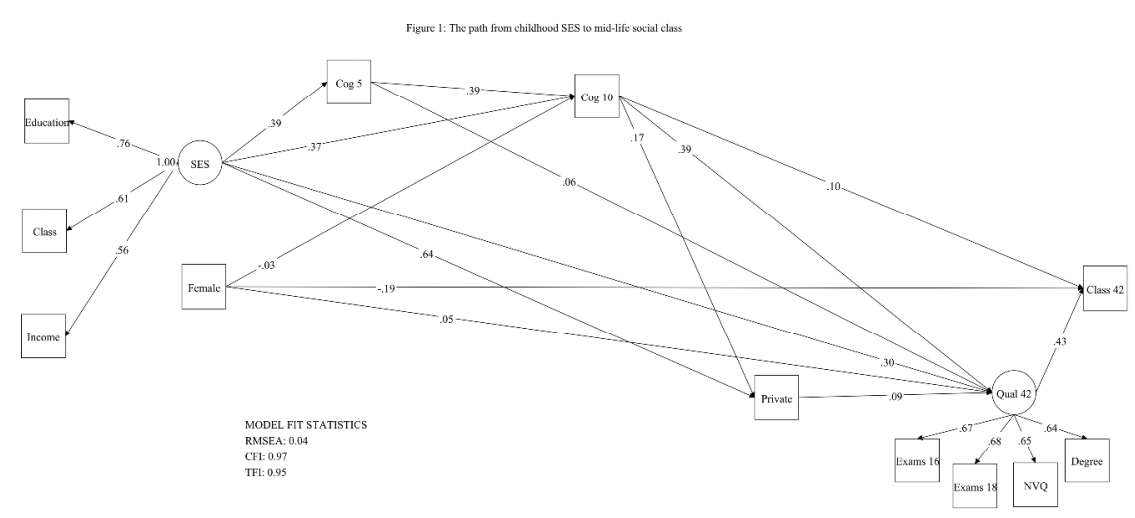

$2786 \times 1267 \mathrm{~mm}(72 \times 72 \mathrm{DPI})$ 